\title{
Incidence and Determinants of Educated-Youth Unemployment in Rajshahi City of Bangladesh
}

\author{
Ataul Gani Osmani ${ }^{*}$, Rakibul Islam ${ }^{* *}$, Habibur Rahman ${ }^{* * *}$, Al-Amin $^{* * * *}$ \\ * Assistant Professor, Department of Economics, Varendra University, Rajshahi 6204, Bangladesh \\ e-mail: ataul@vu.edu.bd \\ ** Lecturer, Department of Economics, Varendra University, Rajshahi 6204, Bangladesh \\ *** Research Assistant, Department of Economics, Varendra University, Rajshahi 6204, Bangladesh \\ **** Research Assistant, Department of Economics, Varendra University, Rajshahi 6204, Bangladesh
}

DOI: 10.51865/EITC.2021.01.07

\begin{abstract}
This study presents the incidence and determinants of unemployment among educated youths in Rajshahi city of Bangladesh. For this purpose, the study analyses primary data collected from randomly selected 250 graduated students of different educational institutions in Rajshahi city by applying two-fold approaches, such as descriptive statistics, and logistic regression analysis. The descriptive statistics approach finds the rate of unemployment among educated youths in the city is $59.2 \%$ and the mean duration of unemployment is 2.5 years. The logistic regression results find that the probability of being unemployed will be decreased if the educated youths are migrated to Dhaka city, have internet access, and are connected with social network but if they have job preferences, the probability of being unemployment will be increased. Therefore, institutional facilities, job related trainings, and the development of service sector in Rajshahi city can be crucial solution of the problem.
\end{abstract}

Keywords: youth unemployment; urban; vulnerability; determinant; haphazard lifestyles.

JEL Classification: E24; J64; R10.

\section{Introduction}

Unemployment is one of the long-lasting challenges of both developed and developing countries (UN, 2012; Kahraman, 2011). It is a form of social evil which undercuts productivity, expenditure and investment of a country that prevents sustainable growth. Any form of unemployment incites tension to the society and raises inequality to an economy (ILO, 1998). Urban unemployment is a rising concern for Bangladesh economy (World Bank, 2015). Figure 1 illustrates the youth unemployment in Bangladesh according to the age group between 15 to 24 years. This figure reveals that the youth unemployment rate in the country is gradually rising from 2010 to 2017 whereas it fluctuates at higher rate from 2000 to 2010. Thus, it can be said that there remains a positive relationship between the youth unemployment and the time period (2000-2018) as the line graph is mostly upward sloping. It is also estimated by Paul (2018) that almost 2 million jobseekers enter the labour market in Bangladesh every year but the country cannot give formal jobs to even one-fourth of them. 


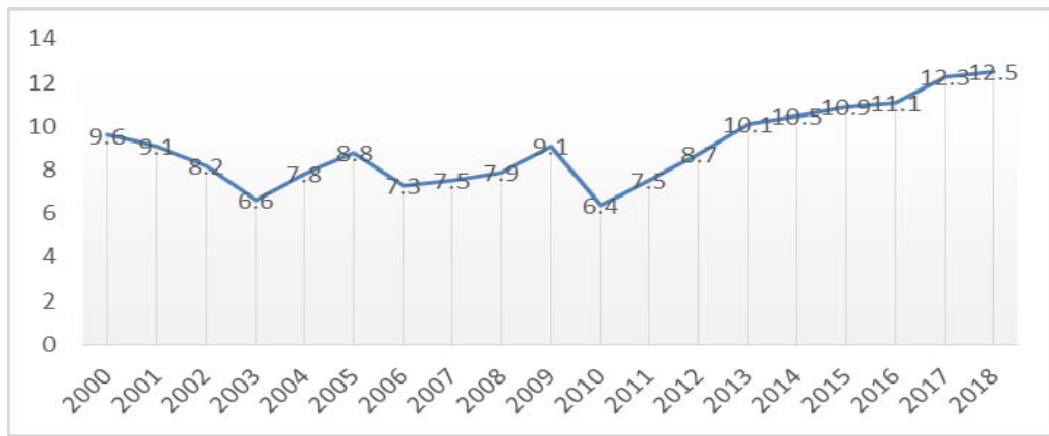

Fig. 1. Youth unemployment of Bangladesh age group 15-24

Source: ILO Estimate, Nov. 2018.

Although the rural economy of the country has witnessed a greater pace of employment creation through non-farm jobs, the creation of employment is so difficult in urban areas. It is observed that despite a decrease in the rate of unemployment in Bangladesh from 5.1\% in 2009 to $4.30 \%$ in 2014, the urban unemployment rate is alarmingly increasing (BBS, 2014). Urban unemployment rate in Bangladesh is $6.45 \%$ which is almost twice than that of rural unemployment (3.94\%). It is mainly the cause of high unemployment among master's degree holders and engineering and medical students (Ahmed, 2012). According to a report of ILO (2016), about $40 \%$ youths in Bangladesh are completely inactive in the work force aged between 15 to 24 years. It is also observed that about $36 \%$ of urban youth are out of employment (World Bank, 2015). These sorts of youth unemployment are prevalent at a large extent around the urban areas of Bangladesh. This is mainly the result of unplanned migration of a vast majority of young people from rural areas to urban areas (Sohel and Khan, 2015). The following figure 2 shows the youth unemployment rate among both male and female at the urban areas by the education status. The figure indicates that the rate of unemployment among young people with tertiary level education has considerably risen up. According to the latest Labour Force Survey (LFS) by BBS, about $46 \%$ of the total unemployed youth are university graduates. A recent study of the Centre for Policy Dialogue (CPD) also found that the rising unemployment rate among the relatively more educated labour force. This is happening because the youth labour force in Bangladesh lacks the required technical and managerial skills muchneeded in the era of the Fourth Industrial Revolution. It is also found that the rate of unemployment among female-youths is higher than their male counterparts. Young women in Bangladesh face gender bias in employment as $76.2 \%$ of young women are unpaid family workers (BBS).

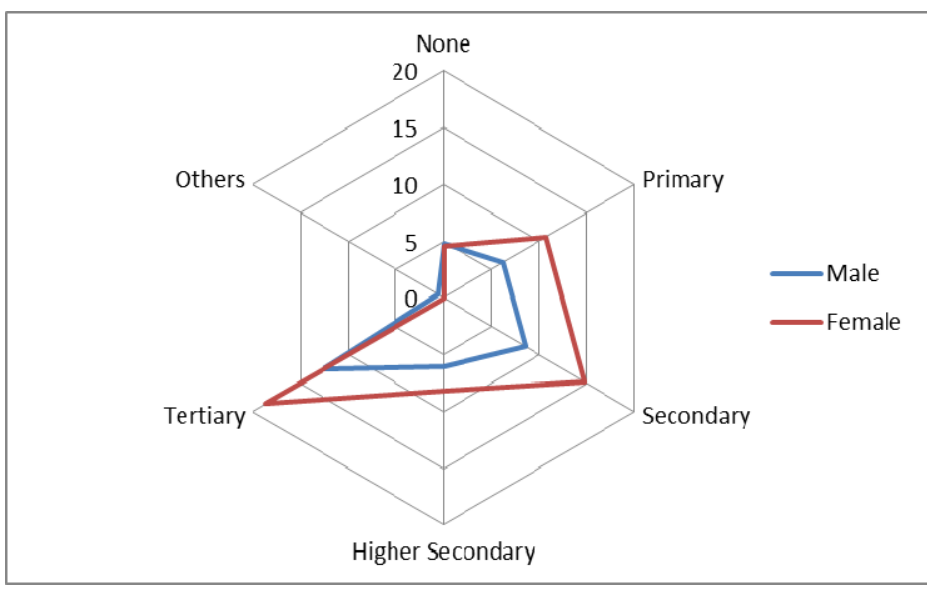

Fig. 2. Urban youth unemployment by education and sex

Source: QLFS-15/16. 
However, several types of unemployment are seen in the urban areas of Bangladesh. Due to the population pressure, cyclical or involuntary unemployment is created as jobs created in urban areas of Bangladesh are not enough for everyone who wants to work. There also exists mismatch between the skill of an unemployed person and the particular skill needed for being employed in urban areas of Bangladesh (Ahmed, 2012). This is an evidence of structural unemployment in urban economy of Bangladesh. Sometimes job seekers and providers fall in a fraught interaction in Bangladesh and hence the problem of frictional unemployment due to the transitional period between job loss and entry to next job is also evident in the country's urban areas (Huda, 2015).

As a result of joblessness and inactivity and the failure to tap into the urban economic aspirations, resources of young people carry higher price and thus, deteriorate the emotional, mental, or physical health of the young generations (ILO, 2008; Knight and Xue, 2006). Despite the flood of research in the field of unemployment, urban youth unemployment is always overlooked by most of researchers in Bangladesh. The scant number of existing earlier studies in the area has been criticized for being poorly designed, devoid of theory and narrow in focus. The goal of the current research is to establish a reliable and valid instrument that will systematically assess the incidence and determinants of urban youth unemployment in Rajshahi city of Bangladesh.

\section{Literature Review}

In drafting the idea for the study of urban youth unemployment, the researchers studied the existing literature comprehensively. The earlier studies on unemployment and even on urban employment are flooded over the world. But the empirical research on the issue of urban youth unemployment is scant. Some of the important earlier studies regarding urban and urban youth unemployment are summarized in the following table.

Table 1. Summarized literature review

\begin{tabular}{|c|c|c|c|c|}
\hline Author/Authors & Year & Subject & Methodology & Findings \\
\hline Serneels & 2004 & $\begin{array}{l}\text { Nature of Urban } \\
\text { Unemployment } \\
\text { (Ethiopia) }\end{array}$ & $\begin{array}{l}\text { Simple } \\
\text { statistics }\end{array}$ & $\begin{array}{l}\text { Almost half of the urban young people } \\
\text { are unemployed who are well-educated } \\
\text { and government job seekers. }\end{array}$ \\
\hline Mitchell & 2013 & $\begin{array}{l}\text { Long-term } \\
\text { unemployment } \\
\text { (USA) }\end{array}$ & $\begin{array}{c}\text { Descriptive } \\
\text { statistics }\end{array}$ & $\begin{array}{l}\text { Most of the long-term unemployed } \\
\text { peoples are uneducated and oldest } \\
\text { where the responsible factors are } \\
\text { racism, gender discrimination, work } \\
\text { limiting disabilities etc. }\end{array}$ \\
\hline $\begin{array}{l}\text { Prakash and } \\
\text { Abraham }\end{array}$ & 2004 & $\begin{array}{l}\text { Urban } \\
\text { unemployment } \\
\text { (Kerala) }\end{array}$ & $\begin{array}{c}\text { Simple } \\
\text { statistics }\end{array}$ & $\begin{array}{l}\text { The growth of urbanization is rapid } \\
\text { and there is an excess supply of } \\
\text { educated young labour force but a slow } \\
\text { growth of organized sector and thereby } \\
\text { urban youth unemployment. }\end{array}$ \\
\hline Nivorozhkin & 2006 & $\begin{array}{l}\text { Risk and duration } \\
\text { of urban } \\
\text { unemployment } \\
\text { (Russia) }\end{array}$ & $\begin{array}{l}\text { Econometrics } \\
\text { and duration } \\
\text { Modeling }\end{array}$ & $\begin{array}{l}\text { About one-third of the unemployed } \\
\text { finds their job easily and rest of them } \\
\text { continues searching. It also found that } \\
\text { with longer duration risk of job } \\
\text { searching tends to decrease. }\end{array}$ \\
\hline Baah-Boateng & 2013 & $\begin{array}{l}\text { Determinants of } \\
\text { unemployment } \\
\text { (Ghana) }\end{array}$ & $\begin{array}{l}\text { Probit } \\
\text { regression } \\
\text { model }\end{array}$ & $\begin{array}{l}\text { Sluggish growth of high labour } \\
\text { absorption sector is the reason of } \\
\text { unemployment as well as a reason of } \\
\text { slower economic growth. And youth } \\
\text { urban dwellers are severely vulnerable. }\end{array}$ \\
\hline
\end{tabular}


Table 1 (cont.)

\begin{tabular}{|c|c|c|c|c|}
\hline $\begin{array}{l}\text { Alivon and } \\
\text { Guillain }\end{array}$ & 2018 & $\begin{array}{l}\text { Urban segregation } \\
\text { and } \\
\text { unemployment } \\
\text { (France) }\end{array}$ & $\begin{array}{l}\text { Spatial probit } \\
\text { model }\end{array}$ & $\begin{array}{l}\text { The probability of unemployment is } \\
\text { higher for the peoples living in a } \\
\text { deprived neighborhood or near a } \\
\text { deprived area. }\end{array}$ \\
\hline $\begin{array}{l}\text { Saungweme et } \\
\text { al. }\end{array}$ & 2014 & $\begin{array}{l}\text { Unemployment, } \\
\text { output and growth } \\
\text { (Zimbabwe) }\end{array}$ & $\begin{array}{l}\text { Log-linear } \\
\text { model }\end{array}$ & $\begin{array}{l}\text { The main forcing factor behind the } \\
\text { thriving informal sector is the } \\
\text { continual collapse of formal job sector. }\end{array}$ \\
\hline Baah-Boateng & 2015 & $\begin{array}{l}\text { Unemployment in } \\
\text { Africa }\end{array}$ & $\begin{array}{l}\text { Scatter plot } \\
\text { and simple } \\
\text { correlation } \\
\text { analysis } \\
\end{array}$ & $\begin{array}{l}\text { There is a significantly negative } \\
\text { correlation between unemployment } \\
\text { and informality. }\end{array}$ \\
\hline Tansel \& Tasci & 2010 & $\begin{array}{l}\text { Determinants of } \\
\text { unemployment } \\
\text { duration (Turkey) }\end{array}$ & $\begin{array}{c}\text { Non- } \\
\text { Parametric } \\
\text { and } \\
\text { parametric } \\
\text { estimation } \\
\text { methods }\end{array}$ & $\begin{array}{l}\text { Unemployment duration of women is } \\
\text { higher than men and age has negative } \\
\text { and education has positive relation } \\
\text { with unemployment. }\end{array}$ \\
\hline ILO & 2008 & $\begin{array}{l}\text { Global } \\
\text { Unemployment } \\
\text { trends of youth }\end{array}$ & $\begin{array}{l}\text { Descriptive } \\
\text { statistics }\end{array}$ & $\begin{array}{l}\text { The rate of youth unemployment is } \\
\text { increased more than four percent in } \\
\text { south Asia (1997-2007). }\end{array}$ \\
\hline Ajaegbu & 2012 & $\begin{array}{l}\text { Unemployment } \\
\text { and Violent } \\
\text { Crime (Nigeria) }\end{array}$ & $\begin{array}{c}\text { The } \\
\text { deprivation } \\
\text { theory } \\
\text { proposed by } \\
\text { Ted Gurr }\end{array}$ & $\begin{array}{l}\text { Feeling of deprivation and frustration } \\
\text { created by unemployment is the reason } \\
\text { of violent crime incurred by youth. }\end{array}$ \\
\hline Okafor & 2011 & $\begin{array}{c}\text { Youth } \\
\text { unemployment } \\
\text { and democracy } \\
\text { (Nigeria) }\end{array}$ & $\begin{array}{l}\text { Descriptive } \\
\text { statistics }\end{array}$ & $\begin{array}{l}\text { The stability of democracy is in danger } \\
\text { because of joblessness youths. }\end{array}$ \\
\hline
\end{tabular}

Source: Summarized by the Authors.

\section{Methodology}

\section{Sources of Data}

There are two main avenues of data sources for the study, such as primary data through personal interviews with the aid of structured question schedule and secondary data from journals, books and other sources. Primary data are collected from listed students of different educational institutions of Rajshahi city, Bangladesh who have completed their studies. These students are now actively searching jobs.

\section{Study Area}

The study is mainly based on primary data which are collected from Rajshahi City Corporation, Rajshahi district, Bangladesh. The city is the most urbanized area than the other districts of northern part in Bangladesh which is both a district and a divisional town, has been flourished day by day. Rajshahi city is on the northern bank of Padma River. The city corporation is mostly populated by high, middle- and lower-income classes. The residents include students, academic professionals, government officials, bank officers, NGO workers, rickshaw pullers, shopkeepers, salesman, day labourers, and domestic workers. 


\section{Sampling Design}

Using a multistage sampling technique, 250 respondents are selected for the study. The first stage is featured as a purposive selection of Rajshahi City Corporation. In the second stage, 5 educational institutions from the existing list are selected randomly. The educational institutions are Rajshahi University, Rajshahi College, Rajshahi Polytechnic College, Varendra University and Barendra College. In the third stage, the lists of students who have passed their final examination are collected from the selected educational institutions. After collecting the list, randomly selected 50 students from each selected institution are interviewed to collect data for our study. This constitutes 250 respondents for the study. The study is restricted to the youth respondents who have completed their final examination and involved into the job market.

\section{Measurement of the Duration of Unemployment}

The gap between employment and the completion of final examination is simply the unemployment duration. The duration is measured in years beginning from the date of result publication and ending with the date of employment and the spell is considered to be rightcensored if an unemployed individual was still unemployed at the end of our observation period. Therefore, following Serneels (2004), the study constructs the measure of unemployment duration as follows as:

$$
\begin{gathered}
\text { Unemployment duration }=\text { Age }(\text { years })-\text { time working (years) }- \text { estimated age at } \\
\text { completing education (years) }
\end{gathered}
$$

\section{Empirical Model for the Determinants of Educated-Youth Unemployment}

In order to find out the reasons of joblessness among educated-youths, it is important to investigate the significant factors of being job seekers without jobs. In formulating the functional form of the model representing the relationship between educated-youth unemployment and hypothesized factors of educated-youth unemployment in Rajshahi city of Bangladesh, the study selects a set of determinants of educated-youth unemployment. The functional model of educated-youth unemployment in Rajshahi city of Bangladesh considers socio-economic both demand side and supply side factors as follows.

$$
E Y U_{i}=f\left(x_{i}\right)
$$

Where, $E Y U_{i}$ is the dependent variable which denotes Educated-Youth Unemployment and $X_{i}$ is the determinants of educated-youth unemployment. At the multivariate analysis, since the dependent variable (unemployed or not) is dichotomous, binary logistic regression model will be fitted. Logistic regression is applied to examine the relationship between urban youth unemployment and a set of factors. The formulated logistic regression model is as follows:

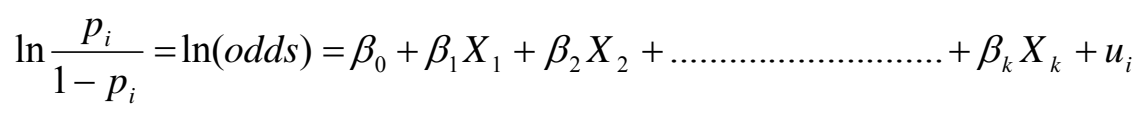

Where, $\beta_{\mathrm{s}}$ are parameters to be estimated and $X_{\mathrm{s}}$ are the factors responsible for educatedyouth unemployment; $p_{i}$ is the probability that $\mathrm{i}^{\text {th }}$ respondent is unemployed and $\left({ }^{1-p_{i}}\right)$ is the probability that the $\mathrm{i}^{\text {th }}$ respondent is employed from the survey data, $\beta$, s are the regression coefficients and the X's are the set of independent variables. From the odds of $\beta$, s are estimated as expectation of $\beta$. The odds ratio is the factor by which the odds of unemployed change per unit change in the $\mathrm{i}^{\text {th }}$ independent variables, controlling the effects of other variables (Johnson 
and Wichern, 2007). The measurements of factors with their expected influences on urban youth unemployment in Rajshahi city are described in the following table.

Table 2. Measurement of the factors affecting educated-youth unemployment

\begin{tabular}{|l|l|l|}
\hline \multicolumn{1}{|c|}{ Factors } & \multicolumn{1}{|c|}{ Measurement/Values } & Expected Signs \\
\hline Age & Age in Years & + - \\
\hline Gender & $0=$ female and 1 = male & + - \\
\hline Technical Education/certificate & $0=$ No and 1= Yes & - \\
\hline Out Migration & $\begin{array}{l}0=\text { still stay at Rajshahi and 1 = migrated } \\
\text { to Dhaka }\end{array}$ & - \\
\hline Access to Internet & $0=$ No and 1 = Yes & - \\
\hline Family Wealth Status & Amount in taka (Bangladeshi currency) & + \\
\hline Social Network & $\begin{array}{l}0=\text { not any network, 1 = has net personal } \\
\text { network }\end{array}$ & - \\
\hline Work experience & $\begin{array}{l}0=\text { no work experience and 1 = has work } \\
\text { experience }\end{array}$ & - \\
\hline Skill Mismatch & $\begin{array}{l}0=\text { skill mismatch and 1 = there is skill } \\
\text { match }\end{array}$ & - \\
\hline Job Preferences & $\begin{array}{l}0=\text { no preference and 1 = has job } \\
\text { preference }\end{array}$ & + \\
\hline
\end{tabular}

Table 2 represents supply side factors such as "age", "gender", "technical education/certificate" and "out migration". These factors are dummies in nature except age. The age variable is measured as continuous variable which may has positive or negative effects on the educatedyouth unemployment. Among the supply side dummy variables, gender may affect the rate of unemployment positively or negatively whereas "technical education/certificate" and "out migration" have negative impact on the educated-youth unemployment. When job seekers have technical education and migrated to Dhaka city (out migration), the chance of being employed may be increased. The demand side factors are "access to internet", "family wealth status", "social network", "work experiences", "skill mismatch" and "job preferences". All the demand side representatives except "family wealth status" are measured as dummy variables. "Family wealth status" and "job preferences" are assumed to affect the rate of educated-youth unemployment positively. Access to internet, social network, work experiences and skill mismatch are hypothesized as negative factors of educated-youth unemployment.

\section{Results and Discussion}

In analysing primary data in line with the objectives of the study, the study finds interesting results. The significant parts of the obtained results are presented and discussed in the following sections.

\section{Distribution of respondents according to the level of education, age marital status and employment situation}

Table 3 reports descriptive statistics for showing the distribution of respondents according to the level of education, marital status and employment situation. Firstly, it is found that Most of the respondents have honour's degree followed by masters and technical degree. As the study objectives are concentrated on youths. The survey finds that most $62 \%$ respondents are aged between 20 to 25 years and other $38 \%$ are aged between $25+$ to 30 years. The survey also finds that only $7 \%$ respondents are married. 
Table 3. Distribution of respondents according to the level of education, age, marital status and employment situation

\begin{tabular}{|l|c|}
\hline \multicolumn{1}{|c|}{ Level of education } & Percentage of 250 respondents \\
\hline Master's & $28.68 \%$ \\
\hline Honor's & $56.32 \%$ \\
\hline Technical Degree or Diploma & $15 \%$ \\
\hline Age & \multicolumn{2}{|c|}{} \\
\hline 20 to 25 years & $62 \%$ \\
\hline $25+$ to 30 years & $38 \%$ \\
\hline Marital Status & \\
\hline Married & $7 \%$ \\
\hline Employment Situation & \\
\hline Public Sector & $7.6 \%$ \\
\hline Private Sector & $12.3 \%$ \\
\hline Part-time & $2.4 \%$ \\
\hline Self-employment/Private Tuition & $18.5 \%$ \\
\hline Unemployed & $59.2 \%$ \\
\hline
\end{tabular}

Source: Authors' calculation from field survey data, 2019.

Table 3 also finds that the youth unemployment rate is quite high in Rajshahi city. It is calculated that $59.2 \%$ of total 250 respondents are unemployed where $12.3 \%$ are employed in private sector and only $7.6 \%$ are involved on public services. This indicates that the rate of urban educated youth-unemployment is alarming for Bangladesh to achieve sustainable development. Moreover, there is a negligible opportunity for part-time jobs.

\section{Duration of educated youth-unemployment in Rajshahi city}

The incidence of unemployment among educated youths in Rajshahi city of Bangladesh is severe as the gap between the date of education completion and the date of employment is large. It is estimated that mean duration unemployment among the youths in Rajshahi city is 2.5 years or 30 months. Figure 3 shows the distribution of respondents by their unemployment duration. It shows that most $57 \%$ of respondents need 2.1 to 2.5 years to be employed.

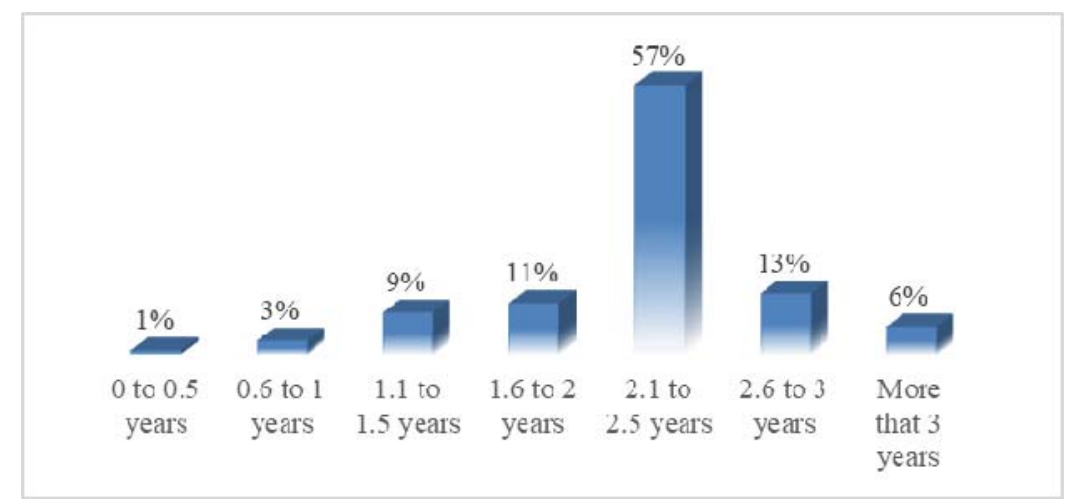

Fig. 3. Distribution of Respondents by the Duration of Unemployment

Source: Authors' calculation from field survey data, 2019. 


\section{Determinants of educated-youth unemployment in Rajshahi city}

The estimation of logistic regression model is performed in IBM SPSS software 23. The estimated logistic regression model (Table 4) is fitted well with the real world data as the results of Hosmer and Lemeshow Test in Table 5 indicates that the Chi-square value is not significant. That is, the model is a representative model than the model without predictor. The Nagelkerke $\mathrm{R}$ Square value is 0.186 which means that about $19 \%$ of variance in educated-youth unemployment is accounted for by the predictors overall. This low value supports the view that Nagelkerke's measure of predictive performance will be lower for the model whose setting has a higher outcome proportion (Riley, et al. 2019). As logistic regression estimation does not account for variance in dependent variable, with low Nagelkerke R Square value the chi-square statistic validates the model's overall fitting (David, 2019). The model has ten explanatory variables and the result determines that four of the variables (out migration, access to internet, social network, and job preferences) are found significant. The estimated model has no serious multicollinearity problem as the average VIF value is 4.26 among the explanatory variables. To avoid the effect of heteroscedasticity, robust logistic regression is employed as it compromises the effect of heteroscedasticity even if it exists initially. The log likelihood ratio test robustly rejects the hypothesis that all slope coefficients are simultaneously equal to zero and thus, the model correctly predicted the observations. The entire variables exhibit hypothesized signs as earlier expectation.

Table 4. Logistic regression results

\begin{tabular}{|l|c|c|c|c|c|}
\hline \multicolumn{1}{|c|}{ Variables } & B & S.E. & Wald & Sig. & Exp(B) \\
\hline Age &. .053 & .044 & 1.423 & .233 & .949 \\
\hline Gender & .096 & .284 & .115 & .735 & 1.101 \\
\hline TechnicalEducationCertificate & .298 & .280 & 1.133 & .287 & 1.347 \\
\hline OutMigration & $-.957^{* * *}$ & .280 & 11.702 & .001 & .384 \\
\hline AccesstoInternet & $-.629 * *$ & .293 & 4.604 & .032 & .533 \\
\hline FamilyWealthStatus & .000 & .000 & .668 & .414 & 1.000 \\
\hline SocialNetwork & $-.959 * * *$ & .280 & 11.755 & .001 & .383 \\
\hline WorkExperience & .024 & .284 & .007 & .933 & 1.024 \\
\hline SkillMismatch & .431 & .278 & 2.396 & .122 & 1.538 \\
\hline JobPreferences & $.637 * * *$ & .286 & 4.946 & .026 & 1.891 \\
\hline Constant & 2.248 & 1.191 & 3.565 & .059 & 9.468 \\
\hline -2 Log likelihood $=303.58 ;$ Number of obs. $=250 ;$ LR chi2 (10) $=37.414 ;$ Prob.> chi2 $=0.0000 ;$ \\
Nagelkerke R Square=0.186 Note: $* * *$ means 1\% and ** means 5\% significance level \\
\hline
\end{tabular}

Source: Authors' calculation from field survey data, 2019.

Table 5. Hosmer and Lemeshow Test

\begin{tabular}{|c|c|c|}
\hline Chi-square & Df & Sig. \\
\hline 7.982 & 8 & .435 \\
\hline
\end{tabular}

The result indicates that 'out migration' negatively affects the probability of being unemployed at 1 percent significance level. Within the category of students who have migrated to Dhaka city (Capital city), odds ratio towards unemployment decreases by .384. It explains that after completing graduation the students who are migrated to the Dhaka city, their probability of being unemployed decreases. It is very true with the researchers' expectation as the capital city is the hub of different job sources but there is rare opportunity to get job in Rajshahi city.

The odds ratio of unemployment decreases by .533 for the individuals who have access to internet compared to those who have not. The educated individuals who can access to internet, they can gather information about the existing competition, application and interview procedures in job sectors in Bangladesh. Those updated information are very essential to get job in any sectors in Bangladesh. 
Social network is important in order to get relevant information about different job opportunities. In recent years, social media sites are very popular and useful to circulate information. Thereby, as it is expected the study finds that active participation in social networking through different social media platforms affect individual's unemployment status negatively and significantly. The odds ratio of being unemployed decreases by .383 (at $1 \%$ significance level), if individuals have net personal networks who helped them in finding a job compared to those who have no social network. That is, the educated job seekers who are active in social media sites with at least one personal account are getting the opportunity of escaping them from joblessness.

On the other hand, as it is relevant that job preferences have positive impact on unemployment, the study finds that job preferences and unemployment are positively related at $1 \%$ significance level. The odds ratio of being unemployed will be increased by 1.891 if any individual has government or high official job choices.

\section{Conclusion}

The study is aimed to investigate the incidence of youth unemployment in Rajshahi city and to investigate the vulnerability and determinants of youth unemployment. This is a unique study in the context of Bangladesh as it applies rigorous methodologies to obtain study objectives. This study is a significant example for further investigation of the severity of youth unemployment in the city areas of Bangladesh. The study finds that both the rate and mean duration of youth unemployment in Rajshahi city are relatively higher than the national rate and duration. It is observed that most of unemployed youths in the city are leading haphazard lifestyles with high level of vulnerability in terms of economic, social and institutional indicators. Moreover, the logistic regression results find that "out migration", "access to internet", "social network" and "job preferences" are the significant determinants of educated youth unemployment in Rajshahi city. Therefore, it is urgent to looking forward towards unemployed educated youths in the city with economic incentives and creating job or entrepreneurship opportunities with awareness and institutional facilities.

\section{Acknowledgement}

The research was supported by a grant from the Center for Interdisciplinary Research (CIR), Varendra University, Rajshahi, Bangladesh. The authors thank Professor Rashidul Haque, Honorable Pro-Vice Chancellor, and Director of CIR, VU, for his constant encouragement and support in this research. The authors declare no conflict of interest with respect to the research reported herein.

\section{References}

1. Ahmed, I. (2012). The urban labour market in Bangladesh. Views \& Opinion, The Financial Express, Dhaka, Vol. 20 No. 218 REGD NO DA 1589.

2. Ajaegbu O. O. (2012). Rising Youth Unemployment and Violent Crime in Nigeria, American Journal of Social Issues \& Humanities Vol.2(5) pp. 315-321.

3. Alivon, F. and Guillain, R. (2018). Urban segregation and unemployment: A case study of the urban area of Marseille-Aix-en-Provence (France). Regional Science and Urban Economics, 72, 143-155.

4. Baah-Boateng, W. (2015). Unemployment in Africa: how appropriate is the global definition and measurement for policy purpose. International Journal of Manpower, 36(5), 650-667.

5. BBS (2014). Bangladesh Unemployment Rate 2003-2016. Available at: http://www.tradingeconomics.com/bangladesh/unemployment-rate. 
6. BBS (2001). Report on labor force survey 1999-2000, Dhaka: Bangladesh Bureau of Statistics (BBS).

7. Huda, S. (2015). Stats mismatch unemployment scenario. Available at: http://en.prothomalo.

8. ILO (1998). General Report on the 15th International Conference of Labour Statisticians. International Labour Office, Geneva.

9. ILO (2008). Global Employment Trends for Youth" International Labour Office, Geneva.

10. ILO (2016). Statistical report of the Decent Work Decade 2006-15: Asia-Pacific and the Arab States. International Labour Organization, Bangkok.

11. Johnson, R.A. and Wichern, D.W. (2007). Applied Multivariate Statistical Analysis, 6th Edition, Pearson Prentice Hall, Upper Saddle River.

12. Kahraman, B. (2011). Youth Employment and Unemployment in Developing Countries: Macro Challenges with Micro Perspectives. Graduate Doctoral Dissertations. Paper 36. Available at: http://scholarworks.umb.edu/doctoral dissertations/36

13. Knight, J. and Xue, J. (2006). How High Is Urban Unemployment in China? Journal of Chinese Economic and Business Studies, Volume 4, 2006, Issue 2.

14. Mitchell, J. (2013). Government Job Losses Hit the Young, the Less educated, and Women the Hardest. Unemployment and Recovery Brief, (11).

15. David, M. (2019). Are high nagelkerke R2 values suspicious in a logistic regression model? Retrieved from: https://www.researchgate.net/post/are high nagelkerke R2 values suspicious in a logistic regress ion model $/ 5 \mathrm{cdf0a} 25 \mathrm{a} 7 \mathrm{cbafe} 1056 \mathrm{cba} 99 /$ citation/download.

16. Okafor, E. E (2011). Youth unemployment and implications for stability of democracy in Nigeria, Journal of sustainable Development in Africa, 13(1), 358-373.

17. Prakash, B. A., and Abraham, M. P. (2004). Employment and Unemployment in Kerala, Kerala's Economic Development: Performance and Problems in the Post Liberalisation Period, 82-101.

18. Riley R.D., Snell K.I.E., Ensor J. et al. (2019). Minimum sample size for developing a multivariable prediction model: PART II - binary and time-to-event outcomes. Statistics in Medicine.38:12761296. https://doi.org/10.1002/sim.7992.

19. Saungweme, T., Matsvai, S. and Sakuhuni, R. C. (2014). Econometric Analysis of Unemployment, Output and Growth of the Informal Sector in Zimbabwe (1985-2013), Int. J. Eco. Res., 2014, v5i2, 01-09.

20. Serneels, P. (2004). The Nature of Unemployment in Urban Ethiopia. CSAE WPS/200401.Universities of Boston, Nottingham, Oxford and Southampton.

21. Sohel, K. and Khan, M.J. (2015). Youth unemployment a big problem for Bangladesh, Dhaka Tribune, The daily Newspaper.

22. Tansel, A. and Taşçı, H. M. (2010). Hazard analysis of unemployment duration by gender in a developing country: The case of Turkey, Labour, 24(4), 501-530.

23. United Nations (2012). Development and Globalization: Facts and Figures, online http://dgff.unctad.org/

24. World Bank (2015). More and Better Jobs to Accelerate Shared Growth and End Extreme Poverty. A Systematic Country Diagnostic. Discussion Draft, South Asia Region, World Bank Group. 